Eur. J. Clin. Chem. Clin. Biochem.

Vol. 32, 1994, pp. 161-167

(c) 1994 Walter de Gruyter \& Co.

Berlin · New York

\title{
Identification of Bordetella Pertussis in Nasopharyngeal Swabs Using the Polymerase Chain Reaction: Evaluation of Detection Methods
}

\author{
By R. Lichtinghagen ${ }^{1}, R$. Diedrich-Glaubitz ${ }^{1}$ and Birgit von Hörsten ${ }^{2}$ \\ ${ }^{1}$ Institut für Klinische Chemie I der Medizinischen Hochschule Hannover, Germany \\ ${ }^{2}$ Abt. Pädiatrische Pneumologie der Kinderklinik der Medizinischen Hochschule Hannover, Germany
}

(Received October 19/December 21, 1993)

Summary: A 183 base pairs or 153 base pairs DNA fragment from a repetitive region of the Bordetella pertussis genome was amplified in a polymerase chain reaction. The sensitivities of three different detection methods (Enzymun Test, silver stained polyacrylamide gel, ethidium bromide stained agarose gel) after amplification by polymerase chain reaction showed that both a one-time polymerase chain reaction ( 35 cycles) with Enzymun testing as well as a nested polymerase chain reaction with either of the electrophoresis methods have high levels of sensitivity for detection of the infectious organism in nasopharyngeal swabs. Smears from 53 children with whooping cough and from 50 children without infections were analysed, using these methods. 51 patients with whooping cough gave positive test results, while 2 of the sick patients and all the control children gave negative results.

\section{Introduction}

Whooping cough is a common, highly contagious, acute infection of the respiratory tract, which is caused by Bordetella pertussis. The majority of the cases are young, non-immunised children and infants. The most severe complications are pneumonia, apnoea and encephalopathy. Reliable detection of the causal agent is usually possible only in the catarrhal stage. From the second week of the paroxysmal stage and in the convalescent stage no $B$. pertussis can be found in the swabs (1).

Bordetella pertussis is a Gram-negative, rod-shaped bacterium which only grows on complex media. Usually, a Bordet-Gengou culture medium is used, which requires immediate inoculation and incubation $(2,3)$. Isolation and identification of bacteria with this method takes many days and gives a significant number of false negative results (4). Immunofluorescence is another possible method, but it requires the bacteria to be cultured and false positive results are often obtained ( 3 , 5-7). A pertussis infection can be detected serologically by quantifying the specific immunoglobulins (IgA, IgM,
IgG) with the ELISA technique (8). The immunoglobulins are detectable at different times after infection. The ELISA seems to have a higher sensitivity than other usual methods of detection (9).

We have described methods for detecting Bordetella pertussis DNA. With the help of the polymerase chain reaction, a specific DNA fragment, found only in $B$. pertussis, can be identified in nasopharyngeal swabs. This area of DNA is a repetitive sequence with 50 to 100 copies per cell and has a total length of 1100 base pairs $(10-15)$. The use of repetitive elements results in an increased sensitivity of the PCR. Different detection methods for the PCR-amplified product were compared. Nasopharyngeal swabs were investigated from 53 patients who were clinically diagnosed with whooping cough, and from 50 patients of a negative control group.

\section{Material and Methods}

Samples

Samples were obtained from patients (children from a paediatric practice between March 1992 and June 1993; two outbreaks) clinically diagnosed with whooping cough and from a negative control 
group (out-patients from the children's hospital of the Medizinische Hochschule Hannover, without any signs of infection or contact with $B$. pertussis infected children). Nasopharyngeal secretions were collected from the nasopharynx with a swab set (Transwab MD 173). The samples wcre placed in $200 \mu$ l physiological saline solution in a stcrile rcaction tube (Eppendorf, $0.5 \mathrm{ml}$ ), resuspended and stored at $-20^{\circ} \mathrm{C}$ until needed.

\section{DNA isolation}

$25 \mu \mathrm{l}$ PCR buffer $(0.1 \mathrm{~mol} / \mathrm{l}$ Tris- $\mathrm{HCl} \mathrm{pH} 9.0,0.5 \mathrm{~mol} / \mathrm{K} \mathrm{KCl}, 10$ $\mathrm{g} / \mathrm{l}$ Triton X-100) and $5 \mu \mathrm{l}$ proteinase-K solution (10 g/l) (Merck) were added to the secretion samples and incubated at $60^{\circ} \mathrm{C}$ for 1 hour. The proteinase- $\mathrm{K}$ was then heat-inactivated by boiling the samples for 10 minutes. The extract was kept on ice until it was used in a PCR or was kept frozen for longer storage.

\section{Implementation of the polymerase chain reaction}

PCR was performed as described by Saiki et al. with some modifications (16). Tetramethylammonium chloride in the reaction mix was used for a more specific annealing reaction (17). In order to obtain a better yield we preferred a hot start PCR.

1. Amplification: $30 \mu$ of the previous treated sample were placed in a $0.5 \mathrm{ml}$ Eppendorf tube, overlaid with $50 \mu \mathrm{l}$ of paraffin and incubated at $95^{\circ} \mathrm{C}$ for 10 minutes (hot start PCR). $20 \mu$ l of Mix I and 2 units of Taq polymerase ${ }^{1)}$ were then added at $80^{\circ} \mathrm{C}$ (Mix I: see below). The PCR was carried out with the primer pair Perl/ Per3rev in a thermocycler (Landgraf) for 35 cycles. The cycles were made up of a denaturation step at $94^{\circ} \mathrm{C}$ for 60 seconds, annealing at $59^{\circ} \mathrm{C}$ for 60 seconds and elongation at $72^{\circ} \mathrm{C}$ for 60 seconds.

2. Amplification or nested PCR: $5 \mu$ from the first amplification were diluted with $200 \mu \mathrm{l}$ of water. Of this, $5 \mu \mathrm{l}$ were added to $45 \mu \mathrm{l}$ PCR Mix II and overlaid with $50 \mu \mathrm{l}$ paraffin. The reaction was carried out with the primer pair Per1/Per2rev for 25 cycles with the same standards as in the first amplification reaction (with the addition of a 2 minute denaturation before the first cycle).

The oligonucleotide sequences were:

PERI: 5'-GAT TCA ATA GGT TGT ATG CAT GGT T-3', PER2-rev: 5'-AAT TGC TGG ACC ATT TCG AGT CGA CG-3', PER3-rev: 5'-GCT TCA GGC ACA CAA ACT TGA TGG-3'.

PCR Mix I (50 $\mu$ l total volume): $0.2 \mathrm{mmol} / \mathrm{d}$ dNTPs (Fa. Pharmacia), $1 \mu \mathrm{mol} / 1$ each of the oligonucleotides (Perl, Per3rev) HPLC grade (Biometra), $2 \mu \mathrm{l}$ PCR buffer (see section DNA isolation), 1.5 $\mathrm{mmol} / \mathrm{l} \mathrm{MgCl}_{2}, 0.05 \mathrm{mmol} / \mathrm{l}$ tetramethylammonium chloride, $2 \mathrm{U}$ Taq polymerase (Cetus, Boehringer Mannheim), ad $20 \mu \mathrm{l} \mathrm{H}_{2} \mathrm{O}$.

PCR Mix II (50 $\mu$ l total volume): $0.2 \mathrm{mmol} / \mathrm{l}$ dNTPs (Fa. Pharmacia), $1 \mu \mathrm{mol} / 1$ each of the oligonucleotides (Perl, Per2rev) HPLC grade (Biometra), $2 \mu \mathrm{l}$ PCR buffer (see section DNA isolation), 1.5 $\mathrm{mmol} / \mathrm{l} \mathrm{MgCl}_{2}, 0.05 \mathrm{mmol} / \mathrm{l}$ tetramethylammonium chloride, $2 \mathrm{U}$ Taq polymerase (Cetus, Boehringer Mannheim), ad $45 \mu \mathrm{l} \mathrm{H}_{2} \mathrm{O}$.

If immunochemical detection was used after the polymerase chain reaction the following changes were made: a 5'-digoxigenin labelled oligonucleotide (dig-Perl primer) was used in the PCR Mix I.

\section{1) Enzymes: \\ Taq polymerase:}

T4 DNA polymerase: T4 polynucleotide

kinase:

EcoRV:

T4 DNA ligase:

\section{Controls}

One positive ( $1 \mathrm{ng}$ cloned DNA from pBluescript $\mathrm{KS}+$ in $200 \mu \mathrm{l}$ $\mathrm{NaCl}$-solution $(8 \mathrm{~g} / \mathrm{l}))$ and one negative control $(200 \mu \mathrm{l} \mathrm{NaCl}$-solution $(8 \mathrm{~g} / \mathrm{l})$ ) were used for each assay run, and were treated in the same manner as the patient samples.

\section{i}

Avoiding contamination in the polymerase chain reaction

In order to avoid false positives resulting from contaminated PCR samples, only sterile pipette tips with filters (Multy Technology Inc.) were used. The risk of contamination was further reduced by using a very simple method of DNA isolation and apportioned stock mixes which reduced the number of pipetting steps. Working areas for sample preparation, PCR and detection of DNA were strictly separated.

\section{Detection of DNA fragments after electrophoretic} separation

\section{Agarose gel electrophoresis}

Ten $\mu \mathrm{l}$ aliquots were mixed with $3 \mu \mathrm{l}$ sample buffer $(100 \mathrm{mmol} / \mathrm{l}$ EDTA, $200 \mathrm{~g} / \mathrm{l}$ Ficoll $400,250 \mathrm{mg} / \mathrm{l}$ bromphenol blue) and applied to a $20 \mathrm{~g} / \mathrm{l}$ agarose gel in tris/borate/EDTA buffer $(89 \mathrm{mmol} / \mathrm{l}$ Trisborate, $89 \mathrm{mmol} / 1$ boric acid, $2 \mathrm{mmol} / 1$ EDTA) (18). Electrophoresis in tris/borate/EDTA buffer containing $400 \mu \mathrm{g} / \mathrm{l}$ ethidium bromide was carried out for 45 minutes with $10 \mathrm{~V} / \mathrm{cm}$. The DNA bands were detected with a UV transilluminator at $312 \mathrm{~nm}$ (18).

\section{Polyacrylamide gel electrophoresis (PAGE)}

Five $\mu \mathrm{l}$ aliquots were mixed with $2 \mu \mathrm{l}$ sample buffer $(100 \mathrm{mmol} / \mathrm{l}$ EDTA, $200 \mathrm{~g} / \mathrm{l}$ Ficoll 400, $250 \mathrm{mg} / \mathrm{l}$ bromphenol blue) and applied to a polyacrylamide gel. The gel consisted of $150 \mathrm{~g} / \mathrm{l}$ acrylamide, $4 \mathrm{~g} / \mathrm{l}$ bisacrylamide, $89 \mathrm{mmol} / \mathrm{l}$ Tris-borate, $89 \mathrm{mmol} / \mathrm{l}$ boric acid, $2 \mathrm{mmol} / \mathrm{l} \mathrm{EDTA}$.

Staining the gel: After electrophoretic separation $(45 \mathrm{~V} / \mathrm{cm})$ the gel was treated $2 \times 3$ minutes in $5 \mathrm{~g} / \mathrm{l}$ acetic acid/100 g/l ethanol, 10 minutes in $2 \mathrm{~g} / \mathrm{l}$ silver nitrate, $2 \times 1 \mathrm{~min}$ in $\mathrm{H}_{2} \mathrm{O}$, ca. 20 minutes in $15 \mathrm{~g} / 1 \mathrm{NaOH} / 0.1 \mathrm{~g} / \mathrm{l} \mathrm{Na-borohydride/1.5} \mathrm{g/l} \mathrm{formaldehyde} \mathrm{and}$ 1 minute in $7.5 \mathrm{~g} / \mathrm{l} \mathrm{Na-carbonate} \mathrm{solution} \mathrm{(19).}$

\section{Partially-automated polyacrylamide gel electrophoresis (Phast- System)}

Each sample area of a PhastGel Sample Applicator 8/1 was covered with $2 \mu \mathrm{l}$ of the aliquot $+1 \mu \mathrm{l}$ of the sample buffer. The electro= phoretic separation was performed on PhastGel (Gradient 8-25 or Homogeneous 20) with Native Buffer Strips and an ensuing silver stain (20) following instructions from Pharmacia $(21,22)$ with slight modifications: SEP. 3 at $400 \mathrm{~V}, 10 \mathrm{~mA}, 2.5 \mathrm{~W}, 15^{\circ} \mathrm{C}, 110 \mathrm{Vh}$.

\section{Immunochemical detection}

\section{Enzymun Test with an ES 300 analyser}

Forty $\mu \mathrm{l}$ of the PCR-specifically amplified and digoxigenin-labelled sample were added to $360 \mu \mathrm{l}$ denaturing reagent $(50 \mathrm{mmol} / \mathrm{l} \mathrm{NaOH})$ and pipetted into the ES 300 analyser. The reaction program,was started according to the Enzymun Test DNA Detection instructions (Boehringer Mannheim). The following reagentts were also necessary: $90 \mu \mathrm{g} / \mathrm{l}$ of the biotinylated capture probe were added to the hybridisation solution (phosphate buffer, $\mathrm{pH}$ 6.5).

\section{Capture probe: 5'Biotin-CTG GAC CAT TTC GAG TCG AC 3'.}

The $B$. pertussis-specific DNA was-detected by the binding of the biotin-labelled nucleic acids to the istreptavidin solid phase (Enzy- 
mun Test ${ }^{R}$ Streptavidin Tubes, Bochringer Mannheim) and the addition of a peroxidase-conjugated anti-digoxigenin antibody to label the digoxigenin. The complex was visualized by addition of the chromogen, di-ammonium 2,2'-azino-bis(3-ethylbenzothiazoline-6sulphonate) (ABTS), which produces a green colour. The intensity was measured at $422 \mathrm{~nm}$ and qualitatively analysed. The positive samples were determined by a cut-off value (cut-off $=2 \times A_{\text {neg }}$ ). Samples with absorbance values between $-25 \%$ and $+50 \%$ of the cut-off value were seen as borderline values and were repeated.

Cloning and sequencing of polymerase chain reaction products in plasmid DNA

Ten $\mu$ l of a PCR sample were separated on a $10 \mathrm{~g} / \mathrm{l}$ agarose gel and the DNA fragment was eluted with the help of the Sephaglas Kit (Pharmacia). The purified DNA was treated with T4 DNA polymerase $^{1)}$ and $\mathrm{T} 4$ polynucleotide kinase ${ }^{1)}(18)$, then ligated to an EcoRV')-prepared vector pBluescript $\mathrm{KS}+$ (Stratagene) with T4 DNA ligase"). This plasmid was amplified in E. coli $\mathrm{C} 600$ and purified with a plasmid kit (Qiagen) after an alkaline lysis of the bacteria (18).

The DNA was sequenced according to the dideoxyribonucleoside triphosphate method with a T7 Sequencing Kit (Pharmacia).

\section{Results \\ Choice of the DNA sequence used for polymerase chain reaction}

For detection of specific $B$. pertussis DNA, a repetitive element was chosen which is present in 50 to 100 copies per cell $(11,14,23)$. The serial use of two primer pairs used in PCR amplification produced a DNA fragment of 183 or 153 base pairs, respectively, when reamplification (nested PCR) was used (see fig. 1).

\section{Cloning the positive control in $E$. coli}

Isolated $B$. pertussis DNA from a positive nasopharyngeal swab was PCR-amplified with the primer pair Per1/
Per3rev, and the resulting fragment extracted from an agarose gel. After ligation with the vector pBluescript $\mathrm{KS}+$ (Stratagene) the fragment was amplified in $E$. coli, purified and sequenced (see materials and Methods). The sequence had almost $100 \%$ homology to sequences found in the literature $(11,14,23)$ with the exception of a single base change (see fig. 1). This DNA fragment was used as a positive control and was run parallel to the patient samples in the assay.

Determining the limit of detection of the different methods used after amplification by polymerase chain reaction

Three different methods for detection of the PCR-amplified DNA were compared. When agarose gel electrophoresis is used, the separated DNA bands can be detected under UV light by ethidium bromide intercalation. The polyacrylamide gel electrophoresis is more than $10 \mathrm{ti}$ mes more sensitive in detecting a DNA fragment, when the gels are silver stained (20). This method can be accomplished with a manual system or a partially automated electrophoresis apparatus using purchased gels (Pharmacia) (see Materials and Methods). For a fully automated detection of the amplified DNA, the Enzymun Test (Boehringer Mannheim) was used.

To compare the various methods of detection, the positive control plasmid was diluted from $1 \mathrm{ng}$ to $10^{-8} \mathrm{ng}$ and amplified in a PCR using a reaction mixture containing digoxigenin-labelled primer (dig-Per1) and an unlabelled primer (Per3rev). After amplification, detection was made with the Enzymun Test. A second amplification with Perl and a sequence-internal primer Per2rev was used for electrophoretically detected samples. Table

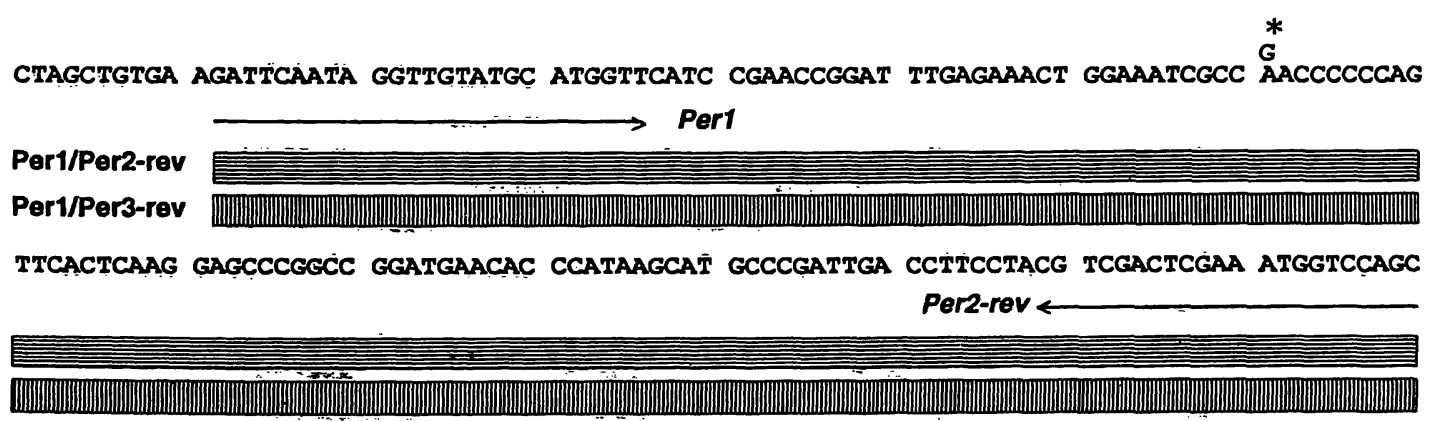

AATTGATCGC CCATCAAGTT TGTGTGCCTG AAGCGGCCCG

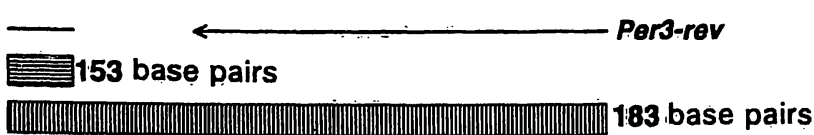

Fig. 1 Sequence of the PCR-amplified DNA from Bordetella pertussis.

The DNA sequence shows a section from a repetitive element in $B$. pertussis which was used to detect specifically the causal organism when used in a PCR. The sequence pictured here is from the pBluescript KS + cloned positive control, which was found in bac- teria taken from a positive nasopharyngeal swab. It differs from the sequence published by $E$. M. Glare et al. by a single base change from $A$ to $G$, indicated by the asterisk. The location and orientation of the primer sequences is shown by arrows, the resulting PCR products by bars. 
Tab. 1 Sensitivity of the individual methods of detection of PCRamplified $B$. pertussis DNA.

The cloned B. pertussis DNA (see fig. 1) was pretreated as a patient sample would be, diluted in several steps $\left(1 \mathrm{ng}-10^{-8} \mathrm{ng}\right)$ and amplified (see Materials and Methods). The limits of detection for the individual methods of detecting are shown. In the Enzymun Test (streptavidin technique), the measurements were always made after the first amplification, whereas a second amplification in the form of a nested PCR was necessary for detection with electrophoretic methods.

\begin{tabular}{|c|c|c|c|c|c|c|c|}
\hline & \multicolumn{7}{|c|}{ DNA [ng] } \\
\hline & 1 & $10^{-3}$ & $10^{-4}$ & $10^{-5}$ & $10^{-6}$ & $10^{-7}$ & $10^{-8}$ \\
\hline & \multicolumn{7}{|c|}{ Number of bacterial cells } \\
\hline & $3 \cdot 10^{6}$ & $3 \cdot 10^{3}$ & $3 \cdot 10^{2}$ & $3 \cdot 10^{1}$ & 3 & $3 \cdot 10^{-1}$ & $3 \cdot 10^{-2}$ \\
\hline $\begin{array}{l}\text { Agarose gel (1. Amplification) } \\
\text { (Ethidium bromide staining) }\end{array}$ & + & - & - & - & - & - & - \\
\hline Agarose gel (2. Amplification) & + & + & + & + & - & - & - \\
\hline $\begin{array}{l}\text { Polyacrylamide gel (1. Amplification) } \\
\text { (Silver staining) }\end{array}$ & + & + & - & - & - & - & - \\
\hline Polyacrylamide gel (2. Amplification) & + & + & + & + & + & - & - \\
\hline $\begin{array}{l}\text { Enzymun-Test } \\
\text { (ES } 300 \text { analyser) }\end{array}$ & + & + & + & + & - & - & - \\
\hline
\end{tabular}

1 shows the results of this comparison. Here, it is shown that the agarose gel electrophoresis has the same sensitivity as the Enzymun Test after the first amplification, when coupled with the nested PCR. By using a capture probe, the Enzymun Test (see Material and Methods) has a specificity comparable to the nested PCR. Silver staining of PCR-amplified products separated on polyacrylamide gels after a nested PCR, is shown to be the most sensitive method. The same level of detection was obtained with both the Phastsystem (Pharmacia) and a common vertical PAGE system. With 100 copies of the detectable DNA sequence per cell only 3 bacteria per PCR run would be necessary (in comparison, 30 cells would be needed for the Enzymun Test or agarose gel electrophoresis after nested PCR).

\section{Comparison of the methods of detection in patient samples}

Fifty-three nasopharyngeal swabs from $B$. pertussis infected children and 50 samples from a negative control group were tested and the results compared. Investigation of the negative control group samples resulted in all cases in the expected negative test findings. Fifty-one out of 53 samples from the positive test pool had positive test results and the 2 remaining samples tested negative in both the nested PCR and the Enzymun Test. Figure 2 shows a comparison of the sensitivity of the various detection methods from several patient samples with different contents of $B$. pertussis (one negative test and seven positive test samples). Uniform results are seen only in samples $1,8, \mathrm{P}$ (positive control) and $\mathrm{N}$ (negative control). In all other cases there were no recog- nisable products after the first PCR amplification when run on an agarose gel. Here, the silver staining technique is also near to its detection limit. With the Enzymun Test even the most weakly positive patient samples exhibited signals many times higher than the negative control. The results with this method were identical to those from a nested PCR followed by electrophoresis. Figure 3 shows the absorbances measured with the ES 300 for the entire negative pool, the positive pool and the negative and positive controls. The values of the 51 positive samples are clearly higher than the calculated cut:off values $\left(2 \times A_{\text {neg }}\right)$. The absorbances of the 50 negative patient samples had an average value of $\bar{x}=0.071$ with a standard deviation of $\mathrm{SD}=0.01$. These values are in good agreement with the results of the negative control runs (Mean value 0.066 , SD $0.01, \mathrm{n} 10$ ).

\section{Discussion}

In this paper the possibility of using the PCR in connection with various methods of detection was studied; in order to determine whether $B$. pertussis can be detected quickly and with a high degree of sensitivity in nașopharyngeal swabs from whooping cough patients. Gllare et al. (23) have stated that a DNA sequence from this repetitive region can be detected on an agrose gel after one PCR of 30 cycles using nasopharyngeal aspirates. We found that the sensitivity and specificity of the different methods of detection requires a nested PCR with electrophoretic detection or a one-time PCR followed by an Enzymun Test, in order to detect the infecting bacteria reliably in nasopharyngeal swàbs. 


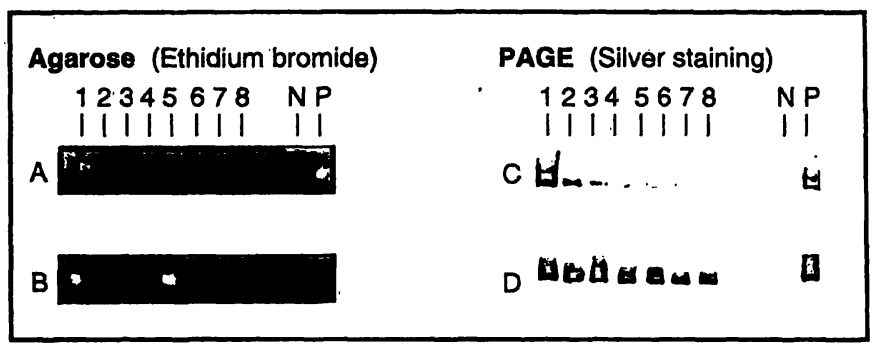

\begin{tabular}{|c|c|c|c|c|c|c|c|c|c|c|}
\hline$E$ & 1 & 2 & 3 & 4 & 5 & 6 & 7 & 8 & $\mathrm{~N}$ & $P$ \\
\hline $\begin{array}{l}\text { Enzymun Test } \\
\text { (ES 300) }\end{array}$ & $\begin{array}{l}+ \\
6.93 \\
(88)\end{array}$ & $\begin{array}{l}+ \\
5.15 \\
(65)\end{array}$ & $\begin{array}{l}+ \\
4.70 \\
(59)\end{array}$ & $\begin{array}{l}+ \\
2.82 \\
(36)\end{array}$ & $\begin{array}{l}+ \\
2.01 \\
(25)\end{array}$ & $\begin{array}{l}+ \\
1.87 \\
(24)\end{array}$ & $\begin{array}{l}+ \\
1.15 \\
(15)\end{array}$ & $\begin{array}{l}- \\
0.08 \\
\text { (I) }\end{array}$ & $\begin{array}{l}- \\
0.08 \\
\text { (I) }\end{array}$ & $\begin{array}{l}+ \\
6.66 \\
(84)\end{array}$ \\
\hline $\begin{array}{l}\text { Agarose gel } \\
\text { (1. Amplification) }\end{array}$ & + & - & - & - & - & - & - & - & - & + \\
\hline $\begin{array}{l}\text { Agarose gel } \\
\text { (2. Amplification) }\end{array}$ & + & + & + & + & + & + & + & - & - & + \\
\hline $\begin{array}{l}\text { PAGE } \\
\text { (1. Amplification) }\end{array}$ & + & + & + & + & + & + & - & - & - & + \\
\hline $\begin{array}{l}\text { PAGE } \\
\text { (2. Amplification) }\end{array}$ & + & + & + & + & + & + & + & - & - & + \\
\hline
\end{tabular}

Fig. 2 Comparison of the sensitivity of the individual methods of detection for weakly positive patient samples.

Eight patient samples were chosen (seven nasopharyngeal swabs with suspected $B$. pertussis infection and one negative patient sample) in which decreasing numbers of bacteria gave results which ranged from positive to negative. These samples were run simultaneously to test three methods of detection after successful PCR. The results are shown after agarose gel electrophoresis (ethidium bromide staining):

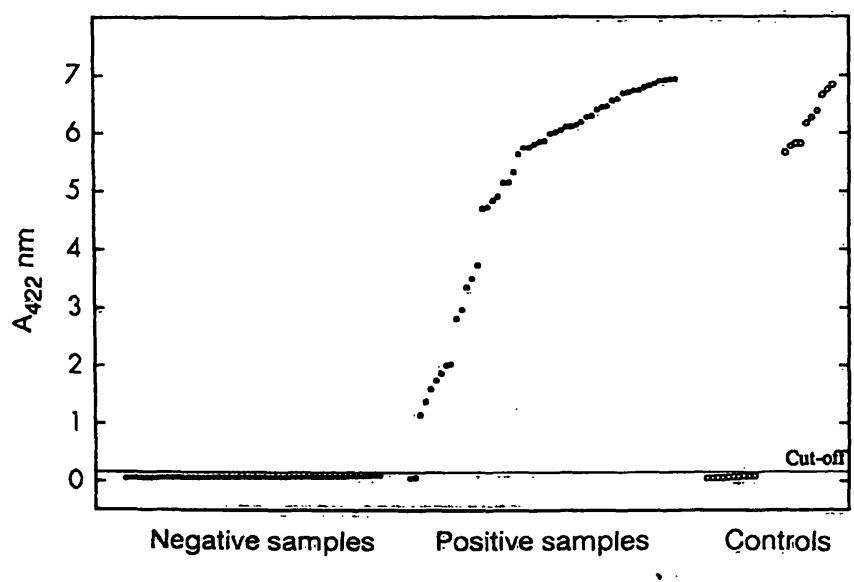

Fig. 3 Distribution of the measured values after detection of the PCR products with the ES 300 analyser (Enzymun Test).

Absorbance values at $422 \mathrm{~nm}$ are listed for increasing concentrations of samples. 50 negative samples (Mean $=0.071, \mathrm{SD}=0.01$ ), 53 positive samples ( 2 negative, 51 positive), 10 negative controls (Mean $=0.067, \mathrm{SD}=0.01, \mathrm{CV}_{\text {inter-assay }}=19 \%$ ), 10 positive controls (Mean $\left.=6.211, \mathrm{SD}=0.5, \mathrm{CV}_{\text {inter-assay }}=6.6 \%\right)$.

The principle of the Enzymun Test would lend itself to a semi-quantitative estimation of the number of bacteria. However, since the quality of the nasopharyngeal swabs
(A) first amplification, (B) second amplification; and polyacrylamide gel electrophoresis (silver staining): (C) first amplification, (D) second amplification.

Table (E) shows the results generated with the individual electrophoretic techniques. These are compared with the results of the streptavidin method (see Materials and Methods). A single PCR amplification of 35 cycles was necessary for measurement with the Enzymun Test. The values shown are related to the photometric absorbance at $422 \mathrm{~nm}$. The values in parentheses are the repeated negative controls.

can vary and the standardisation is difficult, the measured absorption should not be correlated to the actual germ number in the respiratory tract. It should be kept in mind that dead cells can also be detected by this method as opposed to the culture of living cells (8) (see tab. 2).

In most cases $B$. pertussis is no longer detectable after the second week of the paroxysmal stage. At this time no bacteria are found in the nasopharyngeal area. Both negative results in the positive patient pool were from patients who had reached this stage of the disease, and are explained by this fact. In this late phase, the paediatrician's diagnosis is definite, but the use of antibiotics is no longer meaningful. Therefore, the methods described here are more applicable to early diagnosis. The PCR assay is faster (results are obtained within one day) than other methods described so far, since enrichment of the organism is no longer necessary or, as in a serological test, an increased antibody titre is not a requirement (8). Furthermore, fully automated detection of PCR products proved to be very practical in the daily routine. It also decreases the risk of false positive results due to 
Tub. 2 Comparison of laboratory methods for the diagnosis of $B$. pertussis.

The relative sensitivity and specificity of the individual methods are graded from low $(+)$ to high $(++++)$.

\begin{tabular}{llll}
\hline & $\begin{array}{l}\text { Relative } \\
\text { sensitivity }\end{array}$ & $\begin{array}{l}\text { Relative } \\
\text { specificity }\end{array}$ & Advantages/Disadvantages \\
\hline Culture & ++ & ++++ & $\begin{array}{l}\text { Gold standard, positive early' in illness, requires viable or- } \\
\text { ganisms, } 3-7 \text { days for results, often false negative results }\end{array}$ \\
Immunofluorescence & ++ & ++ & $\begin{array}{l}\text { Positive early in illness, viable organisms not required, } \\
\text { rapid results, difficult to interpret }\end{array}$ \\
ELISA serology & +++ & +++ & $\begin{array}{l}\text { Positive late in illness, less sensitive in infants } \\
\text { Polymerase chain reaction }\end{array}$ \\
& ++++ & ++++ & $\begin{array}{l}\text { Positive early in illness, viable organisms not required, } \\
\text { rapid results and high specificity, contaminations due to } \\
\text { false positive results }\end{array}$ \\
\hline
\end{tabular}

contaminations which could occur in a nested PCR assay.

The culture assay and immunofluorescence are not as sensitive as the PCR method. Recently, high proportions of false-negative culture results were found in two other studies, while the PCR had a sensitivity of about $100 \%$ $(23,24)$.

A meaningful advance would be the ability to detect the organism while patients are still in the incubation period. A first insight has been possible with several samples from children who had proven contact with infected children. In several cases $B$. pertussis was detected although no symptoms of the infection were found. These results allow detection of Bordetella pertussis in suspected cases before the clinical symptoms of whooping cough appear. Further studies are needed to pinpoint the

\section{References}

1. Kwantes, W., Joynson, D. H. M. \& Williams, W. O. (1983) Bordetella pertussis isolation in general practice: 1977-79 Whooping cough epidemic in West Glamorgan. J. Hyg. (London) $90,148-158$.

2. Eldering, G. \& Kendrick, P. L. (1952) Incidence of parapertussis in the Grand Rapids area as indicated by 16 years experience with diagnostic cultures. Amer. J. Publ. Hlth. 42, 27-31.

3. Kendrick, P. L. (1971) Current diagnostic procedures in whooping cough. Hlth. Lab. Sci. 8, 206-209.

4. Linneman, C. C. (1978) Host-parasite interactions in pertussis. In: International Symposium on Pertussis (Manclark, C. R. \& Hill, J. C., eds.) U.S. Department of Health, Education and Welfare, Bethesda, Md., pp. 3-18.

5. Donaldson, P. \& Whitaker, J. A. (1960) Diagnosis of pertussis by fluorescent antibody staining of nasopharyngeal smears. Amer. J. Dis. Child. 99, 423-426.

6. Kendrick, P. L., Eldering, G. \& Eveland, W. C. (1961) Fluorescent antibody techniques. Methods for identification of Bordetella pertussis. Amer. J. Dis. Child. 101, 149-152.

7. Whitaker, J., Ronaldson, P. \& Nelson, J. D. (1960) Diagnosis of pertussis by fluorescent antibody method. New Engl. J. Med. 263, 850-852. earliest time at which a reliable diagnosis can be made after infection and before the end of the incubation period.

In some instances a specific probe for all human pathogenic bordetellae species would be helpful. Especially if negative $B$. pertussis-specific PCR results do not correspond to the clinical presentation, additional information can be obtained by PCR of the adenylate cyclase gene, which is specific for all bordetellae species except B. avium (25).

\section{Acknowledgement}

The authors highly appreciate the skilful technical assistance of Bernadette Lüns. We are grateful to Dr. M. Scherf and Dr. U. Fahlbusch for supplying us with the nasopharyngeal swabs and for helpful discussion. We thank Boehringer Mannheim for support, which made part of this work possible.
8. Onorato, I. M. \& Wassilak, S. G. F. (1987) Laboratory diagnosis of pertussis: The state of the art. The Pediatr. Infect. Dis. J. $6,145-151$.

9. Granström, M., Lindberg, A. A., Askelöt, P. \& Hederstedt, B. (1982) Detection of antibodies in human serum against the fimbrial haemagglutinin of Bordetella pertussis by enzymelinked immunosorbent assay. J. Med. Microbiol. 15, 85-96.

10. Alsheikhly, A. R. \& Löfdahl, S. (1989) Identification of a DNA fragment in the genome of Bordetella pertussis carrying repeated DNA sequences also present in other Bordetella species. Microb. Pathog. 6, 193-201.

11. McLafferty, M. A., Harcus, D. R. \& Hewilett, E. L. (1988) Nucleotide sequence and characterization of a repetitive DNA element from the genome of Bordetella pertussis with characteristics of an insertion sequence. J. Gen. Microbiol. 134, 2297-2306.

12. McPheat, W. L. \& McNally, T. (1987) Phase I and phase IV strains of Bordetella pertussis carry a repeated DNA sequence not found in other Bordetella species. FEMS Microbiol. Lett. 41, 357-360.

13. McPheat, W. L. \& McNally, T. (1987) Isolation of a repeated DNA sequence from Bordetella pertussis. J. Gen. Microbiol.
$133,323-330$. 
14. Park, 1., Saurin, W. \& Ullmann, A. (1988) A highly conserved 530 base-pair repeated DNA sequence specific for Bordetella pertussis. FEMS Microbiol. Lett. 52, 19-24.

15. Olcen, P., Backman, A., Johansson, B., Esbjorner, E., Tornqvist, E., Bygraves, J. \& McPheat, W. L. (1992) Amplification of DNA by the polymerase chain reaction for the efficient diagnosis of pertussis. Scand. J. Infect. Dis. 24, 339-345.

16. Saiki, R. K., Gelfand, D. H., Stoffel, S., Scharf, S. J., Higuchi, R. \& Horn, G. T. (1988) Primer-directed enzymatic amplification of DNA with a thermostable DNA polymerase. Science 239, 487-491.

17. Hung, T., Mak, K. \& Fong, K. (1990) A specific enhancer for polymerase chain reaction. Nucl. Acids Res. 18, 4953.

18. Maniatis, T., Fritsch, E. F. \& Sambrook, J. (1982) Molecular Cloning: A Laboratory Manual. Cold Spring Harbor Laboratory, Cold Spring Harbor, N. Y.

19. Kohlmeier, M., Salomon, A., Kersten, B. \& Köttgen, E. (1991) Vereinfachte Genotypisierung von Apolipoprotein E. Eur. J. Clin. Chem. Clin. Biochem. 29, 616-617.

20. Bassam, B. J., Caetano-Annolles, G. \& Gresshoff, P. M. (1991) Fast and sensitive silver staining of DNA in polyacrylamide gels. Anal. Biochem. 196, 80-83.

21. Andersson, A. \& Johansson, J. O. (1987) Rapid purity checking of synthetic oligonucleotides with PhastSystem. J. Biochem. Biophys. Methods 14, 37.
22. Dockhorn-Dworniczak, B., Aulekla-Scholz, C. \& Dworniczak, B. (1990) Schneller Nachweis von Punktmutationen mit Hilfe von PCR-Technik und Elektrophorese mit PhastSystem in der DNA-Diagnostik. Application note A37, Pharmacia-Biotechnology, Uppsala, Schweden.

23. Glare, M. G., Paton, R. P., Lawrence, J. L. \& Nisnet, I. N. (1990) Analysis of a repetitive DNA sequence from Bordetella pertussis and its application to the diagnosis of pertussis using the Polymerase Chain Reaction. J. Clin. Microbiol. 28, 1982-1987.

24. He, Q., Hertsola, J., Soini, H., Skurnik, M., Ruuskanen, O. \& Viljanen, M. K. (1993) Comparison of polymerase chain reaction with culture and enzyme immunoassay for diagnosis of pertussis. J. Clin. Microbiol. 3I, 642-645.

25. Douglas, E., Coote, J. G., Parton, R. \& McPheat, W. (1993) Identification of Bordetella pertussis in nasopharyngeal swaps by PCR amplification of a region of the adenylate cyclase gene. J. Med. Microbiol. 38, 140-144.

\section{Dr. Ralf Lichtinghagen}

Medizinische Hochschule Hannover

Institut für Klinische Chemie I

Konstanty-Gutschow-Straße 8

D-30625 Hannover

Germany 
